\title{
Evaluation of antidiarrheal effect of combination of Salam Leaves (Syzygiumpolyanthum) and Jackfruit Leaves (Artocarpus heterophyllus Lam.) infusum in rats induced by castor oil
}

\author{
Husnul Khuluq, Evi Marlina \\ Department of Pharmaceutical Sciences, Muhammadiyah Health Institute, Kebumen, Indonesia
}

\section{Keywords}

Castor oil induced diarrhoea

Herb medicine

Traditional antidiarrheal herb

Correspondence
Husnul Khuluq
Department of Pharmaceutical Sciences
Muhammadiyah Health Institute
Kebumen
Indonesia
Husnul66@unlidrive.com

\section{Introduction}

Diarrhoea is a major health problem, especially in lowincome countries, which includes Indonesia. In several provinces in Indonesia, the prevalence of diarrhoea is more than 7.0\% (Riskesdas, 2018). Diarrhoea is a bowel movement of fluid that occurs more than three times a day or in frequency more often than that of normal people. One of the processes in the body that causes diarrhoea is a change in the motility of the gastrointestinal tract (Pandango et al., 2018).

Chemical drugs, such as loperamide, can cause side effects, such as abdominal pain, nausea, vomiting, dry mouth, drowsiness, and dizziness. The existence of these side effects causes people to prefer efficacious medicinal plants as alternative medicine (Nurhalimah et al., 2015).

Ethanol extract of Salam leaves (S.polyanthum) has an anti-diarrhoea effect in white mice (Mus Musculus) that have been induced by castor oil (Ambari, 2019). The chemical content contained in salam leaves ( $S$. polyanthum) is tannin, which is known to be effective as an astringent, which can relieve diarrhoea by shrinking the intestinal mucous membrane (Sundari, 2010).

Jackfruit leaves ( $A$. heterophyllus Lam.) is a traditional medicine that has been used empirically by the 
community to treat diarrhoea. Traditionally, these leaves are used by boiling for traditional medicine (Anas et al., 2012). From the antidiarrheal activity of the ethanol extract of jackfruit leaves (Artocarpus heterophyllus Lam.) in mice, it was found that the antidiarrheal activity of both extracts was better than the standard antidiarrheal drug of loperamide (Anas et al., 2012).

The aim of this experimental study was to evaluate the antidiarrheal effect of a combination of Salam leaves, and jackfruit leaves infusum induced by castor oil in rats. The parameters that were measured were the time of diarrhoea/onset of diarrhoea, frequency of diarrhoea, and consistency and number/weight of faeces.

\section{Method}

This experimental laboratory research was designed using a randomised post-test controlled design method. The research was conducted in June 2019 at Pharmacology Laboratory of Muhammadiyah Health Institute, Indonesia, using adult male rats (Rattus norvegicus) with ages between two to four months, with weights between 150-200 g, and good physical health conditions. The rats used were divided into seven treatment groups by random sampling. The amount of replication was determined by using Freeder's formula, and it found 27 research subjects with three rats as a negative control group, three rats as a positive control group, and the other seven rats as a treatment group. Diarrhoea activity data retrieval was done by placing the rats in individual containers for observation.

Prior to implementation, this research proposal had been approved by the Health Ethics Committee of the Faculty of Pharmacy, Ahmad Dahlan University, Jogjakarta, Indonesia, due to the use of rats as experimental animals. This research was conducted in three stages, namely the pre-treatment stage, treatment stage, and data retrieval stage. At the pretreatment stage, a salam and jackfruit leaf infusum was made by mixing the 87.5 grams of fresh leaves powder with $300 \mathrm{~mL}$ of distillate water on a measuring cup then heated and held at a temperature of $90^{\circ} \mathrm{C}$ over a pot containing water for 15 minutes or until the water volume reached $100 \mathrm{~mL}$, after which it was filtered using flannel.

Before treatment, the rats were acclimatised for two weeks with laboratory conditions for self-habituation during the study. At the treatment stage, the animals were divided into nine groups at random, Group I, II, III, IV, V, VI, VII, VIII, and IX. Group I was a Group with Castor oil alone; Group II (positive control) was a Group of rats given $1 \mathrm{ml} / \mathrm{kg}$ bw of tannin; then after one hour, they were given $1 \mathrm{~mL}$ of castor oil orally; Group III and IV were groups of rats treated with $87.5 \%$ salam and jackfruits leaves infusum, and after one hour, they were given $1 \mathrm{~mL}$ of Castor oil orally; Group V-IX were groups of rats treated with mixtures of salam leaf infusum and jackfruit leaf infusum (87.5\%, 1:1, 1:2, 1:3, 2:1 and 3:1), then after one hour, they were given $1 \mathrm{~mL}$ of Castor oil orally. The data retrieval stage about diarrheal activities was done by observation, which included time of diarrhoea, frequency of diarrhoea, consistency and number/weight of faeces, and duration of diarrhoea. The response of each rat was observed at the $30^{\text {th }}, 60^{\text {th }}$, $90^{\text {th }}, 120^{\text {th }}, 150^{\text {th }}, 180^{\text {th }}, 210^{\text {th }}, 240^{\text {th }}, 300^{\text {th }}, 360^{\text {th }}$ minutes after it was given the Castor oil. One-way ANOVA was used to analyse the results; $p<0.05$ was considered statistically significant at the 95 per cent confidence interval.

\section{Results \\ Chemical group test}

Results of different qualitative chemical tests on Salam leaves (S.polyanthum) and Jackfruit leaves (Artocarpus heterophyllus Lam.) with $\mathrm{FeCl}_{3} 5 \%$ and $\mathrm{H}_{2} \mathrm{SO}_{4} \quad 5 \%$ reagents showed the presence of tannin.

Antidiarrheal effect of salam and jack fruit leaves infusum was tested using nine groups of rats, in which each group consisted of three rats. Group II, the negative control group were given $1 \%$ CMC. Group I, as the positive control group, used tannin. The treatment Groups III, IV, V, VI, VII were given mixtures of salam and jackfruit infusum $(1: 1,1: 2,1: 3,2: 1$ and $3: 1)$, and the treatment Groups VII and IX were given salam infusum only and jackfruit infusum only, respectively. An hour later, each rat was given the Castor oil as much as 1 $\mathrm{mL} / \mathrm{rat}$.

The diarrheal activities of the rats in each group can be seen in Table I, in which consistency is converted into the following scores: 0 ) normal faeces; 1 ) soft faeces; 2 ) slimy/watery mass form of faeces; 3 ) not slimy/watery mass form of faeces.

All data parameters were normal and homogenous $(p>$ 0.05 ). Based on the ANOVA test, the significance values between groups in diarrhoea parameters were $p<0.05$ (Table II). This means that there were significant differences between groups.

To know which groups had significant differences, the next test done was the Post Hoc LSD test. From the results of the test analysis, significant differences were found in almost all of the parameters, except at Groups III and IX in weight parameters. The best result based on the $p$-value was Group VII (see Table III). 
Table I: Rats diarrheal activities

\begin{tabular}{|c|c|c|c|c|c|}
\hline Group & Rat & $\begin{array}{l}\text { Total } \\
\text { Frequency }\end{array}$ & $\begin{array}{l}\text { Total } \\
\text { consistency }\end{array}$ & $\begin{array}{l}\text { Consistency } \\
\text { average }\end{array}$ & $\begin{array}{l}\text { Total } \\
\text { weight } \\
\text { (gram) }\end{array}$ \\
\hline \multirow[t]{3}{*}{$I(+)$} & 1 & 4 & 10 & 1 & 2.25 \\
\hline & 2 & 8 & 6 & 0.6 & 2.00 \\
\hline & 3 & 7 & 7 & 0.7 & 1.19 \\
\hline \multirow[t]{3}{*}{ II (-) } & 1 & 31 & 19 & 1.9 & 6.62 \\
\hline & 2 & 26 & 21 & 2.1 & 7.57 \\
\hline & 3 & 18 & 11 & 1.1 & 6.66 \\
\hline \multirow[t]{3}{*}{ III (1:1) } & 1 & 16 & 16 & 1.6 & 4.83 \\
\hline & 2 & 12 & 12 & 1.2 & 6.14 \\
\hline & 3 & 15 & 15 & 1.5 & 7.12 \\
\hline \multirow[t]{3}{*}{ IV (1:2) } & 1 & 13 & 8 & 0.8 & 4.40 \\
\hline & 2 & 10 & 12 & 1.2 & 4.94 \\
\hline & 3 & 5 & 0 & 0 & 5.79 \\
\hline \multirow[t]{3}{*}{$V(1: 3)$} & 1 & 11 & 12 & 1.2 & 5.22 \\
\hline & 2 & 10 & 9 & 0.9 & 4.43 \\
\hline & 3 & 8 & 7 & 0.7 & 4.10 \\
\hline \multirow[t]{3}{*}{ VI $(2: 1)$} & 1 & 13 & 7 & 0.7 & 4.10 \\
\hline & 2 & 9 & 8 & 0.8 & 4.32 \\
\hline & 3 & 10 & 13 & 1.3 & 3.20 \\
\hline VII & 1 & 10 & 9 & 0.9 & 2.88 \\
\hline \multirow[t]{2}{*}{$(3: 1)$} & 2 & 9 & 10 & 1 & 2.25 \\
\hline & 3 & 7 & 7 & 0.7 & 2.00 \\
\hline \multirow{3}{*}{$\begin{array}{l}\text { VIII } \\
\text { (salam) }\end{array}$} & 1 & 9 & 14 & 1.4 & 1.19 \\
\hline & 2 & 10 & 9 & 0.9 & 6.62 \\
\hline & 3 & 7 & 8 & 0.8 & 7.57 \\
\hline \multirow{3}{*}{$\begin{array}{l}\text { IX } \\
\text { (j.fruit) }\end{array}$} & 1 & 15 & 11 & 1.1 & 6.66 \\
\hline & 2 & 9 & 15 & 1.5 & 4.83 \\
\hline & 3 & 11 & 18 & 1.8 & 6.14 \\
\hline
\end{tabular}

(I) Group of rats given Tannins as comparison and then $1 \mathrm{~mL}$ of Castor oil orally; (II) Group of rats given CMC $1 \%$ orally as a control and then $1 \mathrm{~mL}$ of Castor oil orally; (III) Group of rats given infusum of salam and jackfruit mixture (1:1) and then given $1 \mathrm{~mL}$ of Castor oil orally; (IV) Group of rats given infusum of salam and jackfruit mixture (1:2) and then given $1 \mathrm{~mL}$ of Castor oil orally; (V) Group of rats given infusum of salam and jackfruit mixture (1:3) and then given $1 \mathrm{~mL}$ of Castor oil orally; (VI) Group of rats given infusum of salam and jackfruit mixture (2:1) and then given $1 \mathrm{~mL}$ of Castor oil orally; (VII) Group of rats given infusum of salam and jackfruit mixture (3:1) and then given $1 \mathrm{~mL}$ of Castor oil orally; (VIII) Group of rats given infusum of salam only and then given $1 \mathrm{~mL}$ of Castor oil orally; (IX) Group of rats given infusum of jackfruit only and then given $1 \mathrm{~mL}$ of Castor oil orally.
Table II: One way ANOVA test result

\begin{tabular}{ll}
\hline Diarrhoea Parameter & $\boldsymbol{p}$-value \\
\hline Frequency of defecation & 0.001 \\
Faeces consistency & 0.06 \\
Faeces weight & 0.001 \\
\hline
\end{tabular}

\section{Discussion}

In this study, there were significant differences between Groups I and II, where the negative control group was given $1 \% \mathrm{CMC}$ and Castor oil and the positive control group was given tannin before being given castor oil. The positive control group was significantly different from the negative control group in the weight of the stool defecation frequency and faeces consistency. This is consistent with the pharmacological theory, in which diarrhoea results from an imbalance between the absorptive and secretory mechanisms in the intestinal tract, accompanied by hurry, resulting in an excess loss of fluid in the faeces (Horton, 1978).

In some diarrhoeas, the secretory component is predominant, while other diarrhoeas were characterised by hypermotility. It is logical because the autacoids and prostaglandins are involved in producing diarrhoea in humans. Other factors have been suggested to describe castor oil's diarrheal effect: Intestinal $\mathrm{Na}+\mathrm{K}+$ ATPase inhibition reduces normal fluid absorption (Gaginella \& Bass, 1978), adenylate cyclase activation or mucosal cAMP-mediated active secretion (Capasso et al., 1994), prostaglandin production stimulation, and platelet-activating factor stimulation (Pintoy et al., 1992).

Table III: Mean differences and $p$ values based on ANOVA post hoc LSD test

\begin{tabular}{|c|c|c|c|c|c|c|}
\hline Group & $\begin{array}{l}\text { Frequency } \\
p \text {-value }\end{array}$ & $\begin{array}{l}\text { Mean differences } \\
\text { frequency }\end{array}$ & $\begin{array}{l}\text { Consistency } \\
p \text {-value }\end{array}$ & $\begin{array}{l}\text { mean differences } \\
\text { frequency }\end{array}$ & $\begin{array}{l}\text { Weight } \\
p \text {-value }\end{array}$ & $\begin{array}{l}\text { Mean difference } \\
\text { weight }\end{array}$ \\
\hline - vs + & 0.0001 & 18.666 & 0.005 & 0.933 & 0.0001 & 5.136 \\
\hline - vs 1:1 (III) & 0.0001 & 10.666 & 0.374 & 0.266 & 0.098 & 0.920 \\
\hline - vs 1:2 IV) & 0.001 & 15.666 & 0.002 & 1.033 & 0.002 & 1.906 \\
\hline -vs 1:3 (V) & 0.0001 & 15.333 & 0.017 & 0.766 & 0.0001 & 2.366 \\
\hline -vs 2:1 (VI) & 0.0001 & 14.333 & 0.017 & 0.766 & 0.0001 & 3.076 \\
\hline -vs 3:1 (VII) & 0.0001 & 16.333 & 0.011 & 0.833 & 0.0001 & 4.286 \\
\hline -vs salam (VIII) & 0.0001 & 16.333 & 0.035 & 0.666 & 0.001 & 1.980 \\
\hline -vs j.fruit (IX) & 0.0001 & 13.333 & 0.436 & 0.233 & 0.220 & 0.970 \\
\hline
\end{tabular}

Importantly, it has been proposed that nitric oxide leads to castor oil's diarrheal effect (Capasso et al., 1994). Castor oil, on the other hand, is well known to trigger diarrhoea due to its most active ingredient, ricinoleic acid, which triggers a hypersecretory reaction(Meite et al., 2009). The liberation of ricinolic acid from Castor oil results in irritation and inflammation of the intestinal mucosa, leading to the 
release of prostaglandins, which stimulate motility and secretion (Labu et al., 2015).

Tannins have been proven to make the intestinal mucosa more resistant and decrease secretions; furthermore, they suppress the diarrhoea induced by Castor Oil (Hanwa et al., 2007). Tannins present in the plant infusum (salam leaves and jackfruit leaves) are reported to inhibit the release of autacoids and prostaglandins, thereby inhibiting motility and secretion induced by Castor oil. All the treatment group results give significant differences, indicating that all of the groups (salam leaves, jackfruit leaves, or mixtures of salam leaves and jackfruit leaves) infusums had antidiarrheal effects in reducing faeces weight, defecation frequency, and faeces consistency. Hence, tannins as an active compound may be responsible for the antidiarrheal activity. The best result was in Group VII (salam: jackfruit with 3:1 ratio). This means that the optimum dose of inhibition of diarrheal activity from all treatment groups is a mixture of salam leaves and jackfruit leaves infusum with a 3:1 ratio.

\section{Conclusion}

The treatment with a combination of salam leaves and jackfruit leaves infusum in rats induced by Castor oil has an antidiarrheal effect. The best result is a mixture of salam infusum: jackfruit infusum with a 3:1 ratio.

\section{References}

Ambari, Y. (2019). UJI AKTIVITAS ANTIDIARE EKSTRAK ETANOL DAUN SALAM (Eugenia polyantha Wight) PADA MENCIT PUTIH (Mus musculus) JANTAN GALUR BALB-C. Journal of Pharmaceutical Care Anwar Medika, 1(1). https://doi.org/10.36932/j-pham.v1i1.5

Anas, Y., Hidayati, dewi nisa, Kurniasih, A., \& Sanjaya, L. ksatria dwi. (2012). AKTIVITAS ANTIDIARE EKSTRAK ETANOL DAUN NANGKA (Artocarpus heterophyllus Lam.) DAN DAUN ANGSANA (Pterocarpus indicus Wild.) PADA MENCIT JANTAN GALUR BALB/C. 33-41

Capasso, F., Mascolo, N., Izzo, A. A., \& Gaginella, T. S. (1994). Dissociation of castor oil-induced diarrhoea and intestinal mucosal injury in rat: effect of NG-nitro-L-arginine methyl ester. British Journal of Pharmacology, 113(4), 1127-1130. https://doi.org/10.1111/j.1476-5381.1994.tb17113.x

Gaginella, T. S., \& Bass, P. (1978). Laxatives: An update on mechanism of action. Life Sciences, 23(10), 1001-1009. https://doi.org/10.1016/0024-3205(78)90659-8

Hanwa, U. A., Sule, M. I., \& Magaji, M. G. (2007). Antidiarrheal Activity of the Leaf Extract of Stereopermum. Biological and Environmental Sciences Journal for the Tropics, 4(2), 82-86
Horton. (1978). Progress report Prostaglandins and the gastrointestinal tract. 402-417

Kementerian Kesehatan RI Badan Penelitian dan Pengembangan. (2018). Hasil Utama Riset Kesehatan Dasar. Kementrian Kesehatan Republik Indonesia, 1-100

Labu, Z. K., Laboni, F. R., Mamun, M. M. A. Al, \& Howlader, M. S. I. (2015). Antidiarrhoeal activity and total tannin content of ethanolic leaf extract of codiaeum variegatum. Dhaka University Journal of Pharmaceutical Sciences, 14(1), 87-90. https://doi.org/10.3329/dujps.v14i1.23740

Meite, S., N'Guessan, J. D., Bahi, C., Yapi, H. F., Djaman, A. J., \& Guede Guina, F. (2009). Antidiarrheal activity of the ethyl acetate extract of Morinda morindoides in rats. Tropical Journal of Pharmaceutical Research, 8(3), 201-207. https://doi.org/10.4314/tjpr.v8i3.44533

Nurhalimah, H., Wijayanti, N., \& Widyaningsih, T. D. (2015). Efek Antidiare Ekstrak Daun Beluntas pada MencitNurhalimah, dkk. Jurnal Pangan Dan Agroindustri, 3(3), 1083-1094

Pandango, G. C., R. B, R., \& Irwadi, I. (2018). The Effect of Sapodilla Leaves (Achras Zapota) Infusum towards Mice (Mus Muculus) Diarrheal Activity Induced by Oleum Ricini. Biomolecular and Health Science Journal, 1(1), 16. https://doi.org/10.20473/bhsj.v1i1.8194

Pintoy, A., Autore, G., Mascolo, N., Sorrentino, R., Biondi, A., Izzo, A. A., \& Capasso, F. (1992). Time Course of PAF Formation by Gastrointestinal Tissue in Rats After Castor Oil Challenge. Journal of Pharmacy and Pharmacology, 44(3), 224-226.

7158.1992.tb03586.x https://doi.org/10.1111/j.2042-

Sundari \& . M. (2010). STUDI BEBERAPA DOSIS INFUS DAUN SALAM (Syzygium polyanthum Wight Walp) SEBAGAI ANTIDIARE PADA MENCIT (Mus musculus). Farmasains : Jurnal Farmasi Dan IImu Kesehatan, 1(1). https://doi.org/10.22219/far.v1i1.428 